\title{
Transitional Justice, International Law and the United Nations
}

\author{
Leena Grover \\ Associate Professor of International Law, Tilburg Law School, \\ The Netherlands \\ l.k.grover@uvt.nl
}

\begin{abstract}
What relationship does international law have to transitional justice and what role has the United Nations (UN) played in shaping that relationship? The international legal history of this concept reveals that the UN has shifted from relying on international law to support nationally determined transitional justice efforts to expecting States to conform to a growing body of international legal standards it has set in this field. This turn to international legal hegemony and UN managerialism can marginalise some of the most pressing concerns of people attempting to overcome past large-scale abuses. In recent years, the UN has expanded its work in transitioning societies and scholars have recommended ways for better addressing the needs of their members. However, these measures seem partial at best, as they disrupt neither international law's hegemony nor the UN's managerial role in this field, which operate as major constraints on societies weighing their transitional justice options.
\end{abstract}

\section{Keywords}

transitional justice - international law - United Nations (UN)

\section{$1 \quad$ Introduction}

Transitional justice is a hotly contested field, so much so that even its 'field' status is called into question. ${ }^{1}$ It is also marked by a remarkable degree of

1 C. Bell, 'Transitional Justice, Interdisciplinarity and the State of the 'Field' or 'Non-Field", 3(1) International Journal of Transitional Justice (2009) pp. 5-27. Throughout much of this article,

(C) LEENA GROVER, 2019 | DOI:10.1163/15718107-08803002

This is an open access article distributed under the terms of the prevailing CC-BY-NC license at the time of publication. 
dynamism, experiencing multiple phases of development less than 30 years since the concept's inception. ${ }^{2}$ For some, transitional justice concerns how a society overcomes a legacy of large-scale past abuses towards the end of authoritarian rule or conflict. ${ }^{3}$ The corollaries of this understanding are claims that an interdisciplinary discourse properly occupies the field, ${ }^{4}$ as well as trenchant criticisms of purely formal legal approaches to transitional justice. ${ }^{5}$ For others, it is a legal concept that is regulated by international criminal, humanitarian, human rights and refugee laws. ${ }^{6}$ This view regards claims of interdisciplinarity as misplaced. ${ }^{7}$ For all, the concept is at least partly normative and contestation within the 'field' betrays what is actually at stake, namely what and who determine the content of transitional justice, and thereby also the legitimacy of and support for efforts in this field. ${ }^{8}$ In this article, partial responses are offered for both inquiries by attempting to answer two questions. First, what is the structural relationship between international law and transitional justice, meaning to what extent does the former determine the content of the latter (what)? Second, and related to the first, how has the United Nations (UN) shaped this structural relationship (who)? Based on this analysis, a third question is posed. What implications does this structural relationship and the UN's role in this field have for the normative content of transitional justice?

I use the term field absent single quotation marks. This is a stylistic choice. I bracket the question whether transitional justice is a field in order to explore transitional justice's structural relationship to international law. However, the insights gained in this study do shed light on the normative uncertainty pervading the 'field'.

2 R. Teitel, 'Transitional Justice Genealogy', 16 Harvard Human Rights Journal (2003) pp. 69-94.

3 UN, Guidance Note of the Secretary-General: United Nations Approach to Transitional Justice (2010) p. 2 (2010 Guidance Note).

4 This position is perhaps most strongly articulated in the founding mandate of the International Journal of Transitional Justice, which recognizes the interdisciplinary scholarship published under the banner of 'transitional justice' and seeks to "solicit articles from a range of fields and disciplines in order to encourage conversation and debate between diverse perspectives and methodologies", <www.academic.oup.com/ijtj/pages/About>, visited on 16 January 2019.

5 See for example K. McEvoy, 'Beyond Legalism: Towards a Thicker Understanding of Transitional Justice', 34:4 Journal of Law and Society (2007) pp. 411-440.

6 Many of these are collected and available on the website of the UN Office of the High Commissioner for Human Rights, <www.ohchr.org/EN/Issues/TruthJusticeReparation/Pages/InternationalInstruments.aspx $>$, visited on 16 January 2019.

7 Bell, supra note 1.

8 Contestation refers to "activities that resist political and theoretical claims to final, universal, or absolute solutions to political dilemmas”: L. Maxwell, 'Contestation', in Michael T. Gibbons et al. (eds.), The Encyclopedia of Political Thought (Wiley Online Library, New York, 2015). 
This article is divided into two parts. In the first part, the 30 year international legal history of the concept of transitional justice is briefly sketched for the purpose of discerning its relationship to the UN and international law. It is argued that, through the use of soft laws, the UN currently asserts its authority and that of international law to determine the content of transitional justice. In the second part, UN practice and relevant scholarship is critically assessed, namely, prevailing UN understandings of transitional justice, marginalised categories of transitional justice, and remedial steps taken by the UN and recommended by scholars for addressing or capturing these marginalised categories. It is demonstrated inter alia that the UN has traditionally understood ideal 'justice' to be retributive justice for crimes under international law, meaning large-scale violations of civil and political rights. And 'transitional' is understood to mean mechanisms that are exceptional and of limited duration. Ultimately, the UN and scholars' correctives seem to be partial at best, as they do not disrupt the relationship between international law and transitional justice or challenge the UN's questionable managerial authority in this field, which are key normative constraints.

\section{$2 \quad$ International Law and Transitional Justice}

In this section, it will be argued that international law and the UN have had three relationships to transitional justice. During the first phase, transitional justice was an observed national phenomenon that must not violate international legal obligations and the UN was not particularly active in this field. In the second phase, international law was pro-actively studied by the UN and other international actors to buttress national transitional justice efforts that were domestically blocked but could possibly be supported by international law. The third phase is characterised by the UN significantly curtailing national agency in favour of managing or regulating the content of transitional justice pursuant to "international legal standards and obligations". ${ }^{9}$ For present purposes, no attempt is made to rehearse the full history of transitional justice, ${ }^{10}$

92010 Guidance Note, supra note 3.

10 P. Arthur, 'How “Transitions” Reshaped Human Rights: A Conceptual History of Transitional Justice', 31 Human Rights Quarterly (2009) pp. 321-367 (conceptual history); R. Teitel, Transitional Justice (Oxford University Press, Oxford, 200o) (legal history); N. Kritz (ed.), Transitional Justice (2 vols., UsiP Press, Washington, DC, 1995) (general problems and case studies). 
or to explore how different international actors have approached this field (e.g. the International Criminal Court, NGOs).

\subsection{Transitional Justice as National Practice}

The origins of the concept of transitional justice can be traced to three meetings of experts that were held in 1988, 1992 and 1994, and were sponsored by American organisations promoting democratisation. ${ }^{11}$ Experts in attendance understood the concept to be subject to States' international legal obligations. ${ }^{12}$ While legally correct, this observation is surprising not least for two reasons. First, law and policy-makers in transitioning societies in the 1980 s and early 199os did not consider international law to be particularly relevant to their responses to large-scale abuses perpetrated by members of the outgoing regime, including acts of torture, extrajudicial killings, forced disappearances and political repression. ${ }^{13}$ They looked to street protests and public debate, as well as election and referenda results to gauge the will of the people and the demands of victims. They considered political factors, such as the continuing power of the military or the terms of pacted transitions, as well as their own interests. And they looked to national laws to ascertain the scope of legal room to manoeuvre, including constitutional provisions, martial laws on jurisdiction and due obedience, amnesty laws and limitation clauses.

Weighing all of these factors, newly elected governments variously established truth commissions, opened State archives, designed reparation schemes, implemented lustration measures, introduced vetting procedures, carried out

11 Conference, 'Punishment or Pardon?', Aspen Institute, Queenstown, Maryland, USA, 4-6 November 1988; Conference, 'Justice in Times of Transition', Charter 77 Foundation, Salzburg, Austria, 7-10 March 1992; Conference, 'Dealing with the Past', Institute for a Democratic Alternative for South Africa, Somerset West, Western Cape, South Africa, February 1994. Kritz, supra note 10; Teitel, supra note 10; J. Elster, Closing the Books: Transitional Justice in Historical Perspective (Cambridge University Press, Cambridge, 2004). Elster correctly traces the use of transitional justice measures predating these developments, such as the Nuremberg trials. However, these measures were not understood as such at the time.

12 Arthur, supra note 10, p. $35^{2}$.

13 Diane Orentlicher listed the following transitions in her 1991 article: "Uruguay, Chile, Argentina, Brazil, Peru, Bolivia, Honduras, El Salvador, Guatemala, Haiti, Nicaragua, Panama, Uganda, Zimbabwe, Namibia, Benin, the Philippines, South Korea, Nepal, Hungary, Poland, Czechoslovakia, Romania, the former German Democratic Republic, Albania, Bulgaria, and Turkey. Significant liberalization, typically a precursor to the establishment of democratic government, has begun in various other countries, including the U.S.S.R. and many African nations". 'Settling Accounts: The Duty to Prosecute Human Rights Violations of a Prior Regime', 100:8 Yale Law Journal (1991) pp. 2537-2615, p. 2539. 
selective prosecutions and accepted amnesties or pardons for some alleged perpetrators of gross human rights violations. ${ }^{14}$ Structural economic and social injustices were not prioritised by disillusioned socialists involved in bringing these regimes down, and were indeed normatively taboo on the heels of Cold War experiments in distributive justice. ${ }^{15}$ Despite these national and historical contingencies, the injustices addressed and the transitional justice mechanisms selected gave birth to the international concept or understanding of transitional justice.

Second, experts struggled to identify the relevance of international law for transitional justice. At the meeting in 1988 , the answers of Louis Henkin and Theodor Meron to the question of international law's relevance to the concept of transitional justice reminded one attendee "of cavemen who rub sticks of wood together, and a little fire comes up only immediately to die out". ${ }^{16}$ Tellingly, Ruti Teitel's ground-breaking work on transitional justice, published in 2000, is divided into chapters on the rule of law, criminal justice, historical justice, reparatory justice, administrative justice and constitutional justice. ${ }^{17}$ There is no chapter on international justice or the work of the UN.

This is not to say that international human rights law did not play a role in transitions occurring in the 1980 s and 1990s. Indeed, organisations like Amnesty International and Americas Watch (later Human Rights Watch) were worried about a lack of mandate once the regimes they had criticised fell, and were drawn to the concept of transitional justice as a vehicle for continuing their work. ${ }^{18}$ As one UN official reported: "Even before the United Nations began to take action against impunity, non-governmental organisations ... played a pioneering role and began to lay the foundations of a strategy for action. ${ }^{.19}$ More

14 Kritz, supra note 10. Theo Van Boven has defined such violations as follows: "gross violations of human rights and fundamental freedoms which include at least the following: genocide; slavery and slavery-like practices; summary or arbitrary executions; torture and cruel, inhuman or degrading treatment or punishment; enforced disappearance; arbitrary and prolonged detention; deportation or forcible transfer of population; and systematic discrimination, in particular based on race or gender". UN Commission on Human Rights, Study Concerning the Right to Restitution, Compensation and Rehabilitation for Victims of Gross Violations of Human Rights and Fundamental Freedoms: Final Report Submitted by Mr. Theo van Boven, Special Rapporteur (UN Doc. E/CN.4/Sub.2/1993/8) pp. 7-8.

15 Arthur, supra note 10, pp. 337-339.

16 L. Wechsler of The New Yorker, cited in ibid., p. $35^{2}$.

17 Teitel, supra note 10.

18 Arthur, supra note 10, p. 335 .

19 UN Commission on Human Rights, Question of the Impunity of Perpetrators of Human Rights Violations (Civil and Political): Revised Final Report prepared by Mr. Joinet pursuant 
importantly, families of victims of gross human rights violations invoked human rights to normatively contest national amnesty laws in Argentina, Brazil, Chile, El Salvador, Guatemala, Peru and Uruguay. ${ }^{20}$ In a watershed moment, the Inter-American Court of Human Rights held that blanket amnesties for serious human rights violations are incompatible with the human right to a fair hearing. ${ }^{21}$ These early interactions between national law and human rights ushered in a second structural phase.

\subsection{International and Expert Support for Transitional Justice}

Attendees of the meetings requested clarification on the relevance of international law for the concept of transitional justice. ${ }^{22}$ And pursuant to a mandate received by the UN Sub-Commission on Prevention of Discrimination and Protection of Minorities, UN Special Rapporteurs Louis Joinet and El Hadji Guissé were tapped to study impunity for human rights violations. The conversion of a structural inquiry into this limited mandate betrays the extent to which events on the ground shaped the UN's understanding of transitional justice. ${ }^{23}$ Already the focus had shifted from transitional justice to retributive transitional justice. In accordance with the Vienna Declaration and Programme of Action, 'human rights violations' were understood to include all human rights. ${ }^{24}$ Multi-year studies followed involving numerous meetings with NGOS

to Sub-Commission Decision 1996/119 (UN Doc. E/CN.4/Sub. 2/1997/20/Rev. 1), para. 44 (Joinet Principles).

20 See for example Kritz, supra note 10.

21 Inter-American Court of Human Rights, Velásquez Rodriguez v. Honduras, Case 7920, Ser. C., No. 4, IACHR 35, OEA/ser. L/V/III.19 doc. 13 (1988). Victims of gross human rights violations during dictatorial rule mobilised against amnesties in the 1980s, regarding them as guarantees of immunity. However, NGOs, human rights advocates, legal experts and sometimes the democratic opposition in countries like Brazil and Uruguay supported amnesties in the 1970 for political prisoners imprisoned during dictatorial rule, ibid., para. 2. See also C. Binder, 'The Prohibition of Amnesties by the Inter-American Court of Human Rights', 12:5 German Law Journal (2011) pp. 1203-1230; L. Maillinder, Amnesty, Human Rights and Political Transitions: Bridging the Peace and Justice Divide (Hart Publishing, Oxford, 2008).

22 D. Orentlicher, “Settling Accounts' Revisited: Reconciling Global Norms with Local Agency', 1 International Journal of Transitional Justice (2007) pp. 10-22, p. 12.

23 UN, Vienna Declaration and Programme of Action, adopted by the World Conference on Human Rights in Vienna on 25 June 1993, para. 91.

24 UN Commission on Human Rights, Question of the Impunity of Perpetrators of Violations of Human Rights (UN Doc. E/CN.4/RES/1994/44), preamble. 
and States. ${ }^{25}$ However, the mandate was eventually divided, with Joinet reporting on impunity for violating civil and political rights, and Guissé reporting on impunity for violating economic, social and cultural rights. ${ }^{26}$

In 1997, Guissé's mandate concluded with a final report. ${ }^{27}$ In 2005, Joinet's Principles to Combat Impunity (as revised by Diane Orentlicher) were completed and the UN Commission on Human Rights encouraged their widespread dissemination. ${ }^{28}$ Additionally, Theo van Boven was tasked with examining remedies and reparations for gross human rights violations and, after 15 years of negotiations, revised Basic Principles and Guidelines were adopted by the UN General Assembly in 2005. ${ }^{29}$ In the adopted resolution, the General Assembly " $[r]$ ecommends that States take the Basic Principles and Guidelines into account". ${ }^{30}$ In terms of their process or input legitimacy, all of these instruments were drafted by individual experts as opposed to States in the context of formal multilateral negotiations, and these drafting processes differ in transparency. ${ }^{31}$ The extent to which their content was informed by consultations and negotiations with States and other stakeholders varies, as does the extent to which they have been formally endorsed by UN organs.

To appreciate the authority of these reports, principles and guidelines, it is necessary to briefly distinguish between 'soft' and 'hard' international law.

25 N. Roht-Arriaza, 'Combating Impunity: Some Thoughts on the Way Forward', 59:4 Law \& Contemporary Problems (1996) pp. 93-102, p. 96.

26 According to Guissé, this occurred owing to "difficulties of liaison between the two authors and in order to facilitate the treatment of the question": UN Commission of Human Rights, Final Report on the Question of the Impunity of Perpetrators of Human Rights Violations (Economic, Social and Cultural Rights), Prepared by Mr. El Hadji Guissé, Special Rapporteur, pursuant to Sub-Commission Resolution 1996/24 (UN Doc. E/CN.4/Sub.2/1997/8). Ibid.

28 Importantly, the UN Commission on Human Rights did not formally affirm the Joinet/ Orentlicher Principles, nor did it forward them to the UN General Assembly for adoption. Instead it "takes note of them with appreciation": Resolution 2005/81, preamble. UN Commission on Human Rights, Promotion and Protection of Human Rights: Impunity Report of the Independent Expert to Update the Set of Principles to Combat Impunity, Diane Orentlicher. Addendum: Updated Set of Principles for the Protection and Promotion of Human Rights through Action to Combat Impunity (UN Doc. E/CN.4/2005/102/Add.1) (Joinet) Orentlicher Principles).

29 UN General Assembly, Basic Principles and Guidelines on the Right to a Remedy and Reparation for Victims of Gross Violations of International Human Rights Law and Serious Violations of International Humanitarian Law (UN Doc. A/Res/6o/147 (2005)). Van Boven prepared a final report in 1993, supra note 14.

30 Emphasis in original, UN General Assembly, ibid., para. 2.

31 See T. Franck, The Power of Legitimacy Among Nations (Oxford University Press, Oxford, 1990) pp. 17-18. 
Hard laws arise from legal obligations set out in formal sources of international law, which are custom, the operative parts of international conventions, and general principles of law recognised by civilised nations. ${ }^{32}$ Soft laws are best understood as lying along a spectrum with three axes that measure the extent to which they assert obligations for their addressees (usually States), their linguistic precision and their delegation of authority to interpret and implement their content. ${ }^{33}$ Accordingly, the "realm of 'soft' law begins once legal arrangements are weakened along one or more of the dimensions of obligation, precision, and delegation". ${ }^{34}$

In this regard, transitional justice soft laws are striking for their detail and the obligations they attempt to impose on States. Many do not cite hard international legal authorities but are rife with mandatory language addressing what States 'shall' and 'must' do, referring to all manner of duties, rights and guarantees. For example, although the preamble to the 2005 principles to combat impunity states that they "are intended as guidelines to assist States in developing effective measures for combating impunity", they refer to an "inalienable right to know the truth" and a "duty to preserve memory". ${ }^{35}$ While morally intuitive, the legal bases of these purported rights and the wisdom of always remembering have been contested. ${ }^{36}$ Further, these principles provide that "States shall undertake prompt ... investigations of human rights violations and international humanitarian law ... ${ }^{37}$ However, the timing of transitional justice efforts is a politically sensitive matter, not necessarily an international legal obligation. For example, in post-Franco Spain, a conscious decision was made to prioritise strengthening democracy and postpone transitional justice. ${ }^{38}$

32 Statute of the International Court of Justice (adopted 26 June 1945, entered into force 24 October 1945) 33 UNTS 933, articles 38(a), (b) and (c) (ICJ Statute). Article 38(d) provides that "judicial decisions and the teachings of the most highly qualified publicists of the various nations" may serve as a subsidiary means of determining rules of law.

K.W. Abbott and D. Snidal, 'Hard and Soft Law in International Governance', 54:3 International Organizations (2000) pp. 421-456, p. 422. For a strong critique of soft law - that something is either legal or illegal, binding or non-binding, see Jan Klabbers, 'The Redundancy of Soft Law', 65 Nordic Journal of International Law (1996) pp. 167-182.

34 Abbott and Snidal, ibid.

35 Joinet/Orentlicher Principles, supra note 28, Principles 2 and 3.

36 J.A. Sweeney, 'The Elusive Right to Truth in Transitional Human Rights Jurisprudence', 67 International and Comparative Law Quarterly (2018) pp. 353-387, p. 356 et seq. D. Rieff, In Praise of Forgetting (Yale University Press, New Haven, CT, 2016).

37 Emphasis added.Joinet/Orentlicher Principles, supra note 28, Principles 2 and 19.

38 O.G. Encarnación, 'Reconciliation after Democratization: Coping with the Past in Spain', 123:3 Political Science Quarterly (2008), pp. 435-459. 
These soft laws are intended to set the strategic framework for the UN, to aid in the negotiation of peace agreements, as well as to be taken into account by States. ${ }^{39}$ And although they do not state who is delegated authority to interpret or implement them, the International Center for Transitional Justice (ICTJ), a leading NGO in the field, presses for particular UN mechanisms - like the Human Rights Council and various human rights treaty bodies - to enforce them through their existing mandates. ${ }^{40}$

Soft laws can be stepping stones to legalisation but also a means of creating a normative discourse intended to shape political action. ${ }^{41}$ While in theory allowing sufficient room for manoeuvre and contestation, soft laws can also enable diplomatic and moral pressure to be exerted on States, are a means of regulating States' activities, and create expectations. ${ }^{42}$ In turn, the grey zone that emerges "wreaks havoc on juristic concepts", leading inter alia to normative confusion and uncertainty regarding traditional sources of law. This can then blur the line between legally binding and non-binding norms, as well as between international and national legal orders. ${ }^{43}$ One need only consider the normative discourses surrounding the 'fight against impunity' and principle of complementarity to appreciate what happens when the actual content of international law is not sufficiently distinguished from de lege ferenda and policy goals. ${ }^{44}$ However well-intentioned and beneficial soft law transitional justice instruments are, they arguably blur the concepts of law and justice.

$39 \mathrm{UN}$, Report of the Secretary-General on the Rule of Law and Transitional Justice in Conflict and Post-Conflict Societies (UN Doc. S/2004/616), paras. 10-11 (2004 Report).

40 ICTJ, 'Transitional Justice in the United Nations Human Rights Council', IctJ Briefing (June 2011).

41 Abbott and Snidal, supra note 33, pp. 424 and 456. Soft laws can also be a means of collaborating and coordinating with other States.

42 C.M. Chinkin, 'The Challenge of Soft Law: Development and Change in International Law', 38 International and Comparative Law Quarterly (1989) pp. 850-866.

43 Ibid., p. 865; N. Krisch, Beyond Constitutionalism: The Pluralist Structure of Postnational Law (Oxford University Press, Oxford, 2010) pp. 13-14.

44 On the prima facie duty to prosecute crimes under international law see for example $\mathrm{C}$. Kreß and L. Grover, 'International Criminal Law Restraints in Peace Talks to end Armed Conflicts of a Non-international Character', in M. Bergsmo and P. Kalmanovitz (eds.), Law in Peace Negotiations, Forum for International Criminal and Humanitarian Law, No $5\left(2^{\text {nd }}\right.$ ed., International Peace Research Institute, Oslo, 2010) pp. 41-84; M. Scharf, 'The Letter of the Law: The Scope of the International Legal Obligation to Prosecute Human Rights Crimes', 59:4 Law \& Contemporary Problems (1996) pp. 41-61. Maillinder's empirical research reveals a huge disparity in the use of amnesties, with very uneven State practice and few legal trends except for a decline in blanket amnesties and increased use of amnesties since the 199os, supra note 20. On the different lives of complementarity, see S.M.H. Nouwen, 
A heuristic complement to the concepts of soft and hard international law is Nico Krisch's distinction between 'liquid' and 'hard' international authority. ${ }^{45}$ Liquid authority is the gradual consolidation of authority by international actors. This is achieved through deference, which results from dynamic social processes and the development of informal tools rather than commands derived from hard law. Despite qualitative differences, liquid authority is capable of achieving just as much norm compliance as hard authority - just how this is accomplished is the subject of ongoing empirical research. ${ }^{46}$ In the field of transitional justice though, there is evidence that some of this compliance is facilitated by NGOs diffusing these norms and attempting to substitute the political dimension of transitional justice with a technical one. ${ }^{47}$ To take just one example, the ICTJ relies on the UN's soft law instruments as forming "part of the legal basis for the field", and the selection of transitional justice approaches as requiring "technical and comparative expertise" prior to them being "applied".48

The European Union's policy framework on transitional justice also mirrors the UN's state of the art in this field..$^{49}$ Norm diffusion and compliance is also promoted by scholars. In addition to the soft law work carried out by Guissé, Joinet and van Boven, Diane Orentlicher was asked by attendees of the 1988 meeting on transitional justice to clarify the relevance of international law for this field. She responded by producing a foundational study on the scope of the international legal duty to prosecute human rights violations of a prior regime. ${ }^{50}$ Briefly, Orentlicher found that some treaties expressly oblige States to investigate and institute criminal proceedings against alleged perpetrators of particular crimes (e.g. torture). ${ }^{51}$ Under other human

Complementarity in the Line of Fire: The Catalysing Effect of the International Criminal Court in Uganda and Sudan (Cambridge University Press, Cambridge, 2013).

45 N. Krisch, 'Liquid Authority in Global Governance', 9:2 International Theory (2017) pp. 1-20.

46 Ibid.

47 On the professionalisation of transitional justice by NGos, see J. Subotić, 'The Transformation of International Transitional Justice Advocacy', 6 International Journal of Transitional Justice (2012) pp. 106-125.

48 ICTJ, 'Transitional Justice in the United Nations Human Rights Council', ICTJ Briefing (June 2011) pp. 2 and 4.

49 Council of the European Union, Foreign Affairs Council, Council Conclusions on EU's Support to Transitional Justice, 16 November 2015. The European Union is one of the largest financial backers of transitional justice initiatives.

50 Orentlicher, supra note 22.

$5^{1}$ See, however, the aut dedere aut judicare regime in the Convention Against Torture and Other Cruel, Inhuman or Degrading Treatment or Punishment (adopted 10 December 1984, entered into force 26 June 1987) 1465 UNTS 85, articles 6 and 7 . 
rights treaties, she identified duties to investigate acts of torture, extrajudicial killings and forced disappearances..$^{52}$ And under customary international law, she found that "States' general obligation to ensure the enjoyment of fundamental rights was incompatible with wholesale impunity for atrocious crimes but did not require prosecution of every offense".53 Additionally, she stated that "international law itself helps assure the survival of fragile democracies when its clear pronouncement removes certain atrocious crimes from the provincial realm of a country's internal politics and thereby places those crimes squarely within the scope of universal concern and the conscience of all civilized people". ${ }^{4}$ In other words, Orentlicher advocated for transitional justice shifting from the purview of national politics into the domain of international law.

In response to Orentlicher's mix of legal and policy arguments, advocates of a measure of national political discretion spoke up. ${ }^{55}$ Carlos Nino, Argentine philosopher and adviser to President Alfonsin, cautioned against this normative blurring in international law. In so doing, he recalled Dworkin's distinction "between individual rights established by principles and collective goals imposed by policies" to argue that punishing someone for committing a crime is not an individual right held by a victim but rather a collective policy goal. ${ }^{56} \mathrm{Ac}-$ cordingly, Nino asserted that a one-size-fits-all policy of retributive justice at the international level is inapt for transitioning societies, which have to weigh a number of competing factors. ${ }^{57}$

52 One example of this is article 2(2) of the International Covenant on Civil and Political Rights (adopted 16 December 1966, entered into force 23 March 1976) 999 UNTS 171, which obliges States Parties to take legal and other measures to "give effect to the rights recognised in the present Covenant". See also UN Human Rights Committee, General Comment No. 31: The Nature of the General Obligation Imposed on States Parties to the Covenant (UN Doc. CCPR/C/21/Rev.1/Add. 1326 (2004)).

53 D. Orentlicher, "Settling Accounts' Revisited: Reconciling Global Norms with Local Agency', 1 International Journal of Transitional Justice (2007) pp. 10-22, p. 13. Note as well articles 26 and 27 of the Vienna Convention on the Law of Treaties (adopted 23 May 1969, entered into force 27 January 1980) 1155 UNTS 331, which require States to give effect to their treaty obligations in good faith and bars them from invoking internal law as a justification for failure to perform these obligations.

54 Orentlicher, supra note 13, p. 2540.

55 Orentlicher, supra note 53, citing Zalaquett, p. 12.

56 C.S. Nino, 'The Duty to Punish Past Abuses of Human Rights put into Context: The Case of Argentina', 100:10 Yale Law Journal (1991) pp. 2619-2640, p. 2621.

Ibid. 
In 2004, UN Secretary-General Kofi Annan consolidated the organisation's understanding of transitional justice in a report, which acknowledged the legitimate authority of domestic actors to determine transitional injustices and design responses to them at the national level:

[Transitional justice] comprises the full range of processes and mechanisms associated with a society's attempts to come to terms with a legacy of large-scale past abuses, in order to ensure accountability, serve justice and achieve reconciliation. These may include both judicial and nonjudicial mechanisms, with differing levels of international involvement (or none at all) and individual prosecutions, reparations, truth-seeking, institutional reform, vetting and dismissals, or a combination thereof. ${ }^{58}$

However, this report continued to blur the line between applicable international law and policy aspirations flowing from this law. The UN came firmly down on the side of basing its transitional justice work on "international norms and standards because these enjoy greater legitimacy than exported national models, which might not reflect the best interests or legal needs of the 'host' (transitioning) country". ${ }^{9}$ Curiously, although the report contains critical reflections on past practices of the UN, the Secretary-General did not question whether international actors are ideally suited to discern and export the scope and content of transitional justice, or whether they too are vulnerable to reflecting "more the individual interests or experience of donors and assistance providers".60

At the time, the Secretary-General's report could have been welcomed. It was on its face open to people in transitioning societies having the option of international involvement in their transitional justice efforts, which accords with the origins of the concept, and leads to more meaningful and effective outcomes. ${ }^{61}$ This option also respects the rights to internal right selfdetermination and participation in public affairs. ${ }^{62}$ Indeed, it is acknowledged in the report that the international community needs to learn from the past imposition of foreign approaches to transitional justice and instead encourage

\footnotetext{
$58 \quad 2004$ Report, supra note 39, para. 8.

59 Emphasis added, ibid., para. 10.

6o Ibid.

61 онснг, Rule-of-Law Tools for Post-Conflict States: National Consultations on Transitional Justice (UN Doc. HR/PUB/og/2 (2009)), p. V (OHCHR, National Consultations).

62 Articles 1(1) and 25(a).
} 
"nationally led strategies of assessment and consultation carried out with active and meaningful participation of national stakeholders ...". ${ }^{63}$ Kofi Annan also admits that transitional justice raises "as much political questions as technical ones" 64 and that it is a "long-term process". ${ }^{65}$

Perhaps most importantly, Annan emphasised in his report the boundaries rather than the content that international norms and standards impose on the UN's transitional justice work:

for example, United Nations tribunals can never allow for capital punishment, United Nations-endorsed peace agreements can never promise [blanket] amnesties for genocide, war crimes, crimes against humanity or gross violations of human rights, and, where we are mandated to undertake executive or judicial functions, United Nations-operated facilities must scrupulously comply with international standards for human rights in the administration of justice. ${ }^{66}$

Rightly, by addressing the UN's work and not prescribing particular transitional justice responses for States, the report did not challenge the authority of actors other than the UN to create content for the field. After all, the UN itself is arguably exercising assumed (reflexive) rather than delegated authority in transitional justice matters.

In conclusion, up until 2004, the UN understood transitional justice as a concept whose content was shaped inter alia by international and noninternational actors, by law and by politics. In just two years, the UN's approach would decisively shift from support to management.

632004 Report, supra note 39, para. 15.

64 Ibid., para. 19. He even went on to acknowledge the risks associated with ignoring this dimension, para. 20: "And yet, the international community has frequently underestimated the extent of political will necessary to support effective rule of law reform in postconflict States and invested inadequately in public consultations on reform questions. As a result, justice strategies and assistance programmes have sometimes neglected to facilitate consensus among important stakeholders on the nature and pace of reforms and new institutions. Here too the United Nations has a role. Just as we have supported national consultations in the form of elections and referendums, so must we support and facilitate national consultations aimed at determining the national course for transitional justice or rule of law reform" (emphasis added).

65 Ibid., para. 21.

66 Ibid. 


\subsection{International Practice as Transitional Justice}

In the wake of Kofi Annan's report, international transitional justice 'norms and standards' grew in breadth and detail. This is due in part to his decision in 2006 to make the Office of the High Commissioner for Human Rights (OHCHR) the leading UN entity for transitional justice. ${ }^{67}$ Today, understandings of transitional justice are informed not only by hard international legal obligations but also by a dense network of soft laws, including UN principles, resolutions, and reports, as well as a series of OHCHR technical toolkits (Rule-of-Law for Post-Conflict States), which are "grounded in international human rights law and contain lessons learned and best practices from United Nations field operations". 68 These insightful tools address issues such as how to map the justice sector, conduct national prosecutions, establish truth commissions, vet public officials and monitor legal systems. On the ground, the OHCHR's transitional justice work has been summarised as follows:

The Office of the High Commissioner has been supporting transitional justice programmes in more than 20 countries worldwide, including engaging in the design and implementation of inclusive national consultations; supporting the establishment of truth-seeking processes, judicial accountability mechanisms, and reparations programmes; enhancing institutional reform; and ensuring that human rights and transitional justice considerations are reflected in peace agreements. OHCHR provides dedicated transitional justice programmes at the country level; conceptual and policy support at headquarters; and partnerships with multiple actors, including national authorities, national human rights institutions, civil society and other United Nations departments and agencies. 69

The UN Human Rights Council has endorsed the work of the OHCHR and recognised this thick approach to transitional justice grounded in international

67 UN Secretary-General's Policy Committee on the Rule of Law, Decision No. 20o6/47.

68 онснк, Report of the United Nations High Commissioner for Human Rights on Human Rights and Transitional Justice (UN Doc. A/HRC/18/23 (2011)), para. 5 (OHCHR Report). The main instruments are available on the website of the UN Office of the High Commissioner for Human Rights, <www.ohchr.org/EN/Issues/TruthJusticeReparation/Pages/InternationalInstruments.aspx $>$, visited on 16 January 2019. To fully appreciate the breadth and depth of the UN's work in this area, see UN Secretary-General, Uniting our Strengths: Enhancing United Nations Support for the Rule of Law (UN Doc. A /61/636-S /2006/980).

69 онснR Report, ibid., Summary; UN Human Rights Council, Report of the United Nations High Commissioner for Human Rights on Human Rights and Transitional Justice (UN Doc. A/HRC/18/23 (2011)), p. 4. 
human rights. ${ }^{70}$ Since 2005 , the Council has repeatedly emphasised the need for a 'comprehensive' approach to transitional justice:

[The Council] Emphasizes the importance of a comprehensive approach to transitional justice incorporating the full range of judicial and nonjudicial measures, including, among others, individual prosecutions, reparations, truth-seeking, institutional reform, vetting of public employees and officials, or an appropriately conceived combination thereof, in order to, inter alia, ensure accountability, serve justice, provide remedies to victims, promote healing and reconciliation, establish independent oversight of the security system and restore confidence in the institutions of the State and promote the rule of law in accordance with international human rights law; ${ }^{71}$

In other words, multiple transitional justice measures are expected to be used and with a view to achieving ends that go beyond the oft-stated transitional justice goals of accountability, justice and reconciliation. This language can be contrasted with the 2004 report advocating for a 'holistic' approach to transitional justice: "Where transitional justice is required, strategies must be holistic, incorporating integrated attention to individual prosecutions, reparations, truth-seeking, institutional reform, vetting and dismissals, or an appropriately conceived combination thereof." ${ }^{\prime 2}$ Whereas holistic calls attention to the interdependencies of transitional justice measures selected, a comprehensive approach seems to imply that the greater the number of transitional justice measures selected, the better. ${ }^{73}$

The perceived legality and legitimacy of international transitional justice 'norms and standards' has also grown amongst scholars. ${ }^{74}$ For example,

70 UN Human Rights Council, Resolution 12/11: Human Rights and Transitional Justice (UN Doc. A/HRC/RES/12/11 (2009)) para. 20 (Resolution 12/11).

71 Emphasis added: UN Human Rights Council, Resolution 21/15: Human Rights and Transitional Justice (UN Doc. A/HRC/Res/21/15 (2012)) (Resolution 21/15), paras. 1 and 7. See also UN Human Rights Council, Resolution 2005/7o: Human Rights and Transitional Justice (UN Doc. E/CN.4/REs/2005/70), paras. 1-2, 4; Resolution 12/11, supra note 70, para. 4.

$72 \quad 2004$ Report, supra note 39, para. 26.

73 This comprehensive approach was also endorsed by the UN Secretary-General in his 2010 Guidance Note, supra note 3, p. 6.

74 J. Brunnée and S. Toope, Legitimacy and Legality in International Law: An Interactional Account (Cambridge University Press, Cambridge, 2010); T. Altwicker and O. Diggelmann, 'How is Progress Constructed in International Legal Scholarship?', 25:2 European Journal of International Law (2014) pp. 425-444. 
although no UN body has formally adopted the Joinet/Orentlicher principles to combat impunity and they are intended to serve as "a guideline to assist States in developing effective measures for combating impunity", a nearly 500page legal commentary to the principles was published in $2018 . .^{75}$

In 2006, Annan confirmed that transitional justice is "consistently integrated" into the UN's peace operations, thereby linking the field to the organization's mandate to "maintain international peace and security". ${ }^{76} \mathrm{He}$ further confirmed that UN in-country entities, "in consultation with Member States", are responsible for ensuring the "application of standards" to transitional justice activities, and that donors be asked to fund "priority activities in the area concerned". ${ }^{77}$ Indeed, the UN's authority as transitional justice content-creator for (consenting) national takers has gained acceptance.

In concrete terms, the UN has inter alia exported truth and reconciliation commissions to East Timor pursuant to a UN Transitional Administration regulation, as well as to El Salvador and Guatemala through peace accords that the UN respectively sponsored and brokered. ${ }^{78}$ Additionally, the UN Security Council established international criminal tribunals to try Rwandans and citizens of the former Yugoslavia for crimes under international law. ${ }^{79}$ And pursuant to bilateral treaties between the UN and Sierra Leone, as well as Cambodia respectively, hybrid international criminal tribunals were established in these countries. ${ }^{80}$ To be sure, these mechanisms can be seen as positive developments to the extent that they were desired by and meaningful to citizens in these

75 F. Haldemann and T. Unger (eds.), The United Nations Set of Principles to Combat Impunity: A Commentary (Oxford University Press, Oxford, 2018).

76 UN Secretary-General, Uniting our Strengths: Enhancing United Nations Support for the Rule of Law (UN Doc. A /61/636-S /2006/980) Summary (Uniting our Strengths); Charter of the United Nations (adopted 26 June 1945, entered into force 24 October 1945) 1 UNTS XVI, Article 1(1) (UN Charter).

77 Uniting our Strengths, ibid., para. 45.

78 C. Stahn, 'The Geometry of Transitional Justice: Choices of Institutional Design', 18 Leiden Journal of International Law (2005) pp. 425-466, pp. 428-429. A hybrid international criminal tribunal was also established in East Timor pursuant to a UN Transitional Administration regulation.

79 UN Security Council, Resolution 827 (1993) (UN Doc. S/RES/827 (1993)); UN Security Council, Resolution 955 (1994) (UN Doc. S/RES/955 (1994)).

8o Agreement between the United Nations and the Government of Sierra Leone on the Establishment of a Special Court for Sierra Leone (adopted 16 January 2002, entered into force 12 April 2002) 2178 UnTs 137; Agreement between the United Nations and the Royal Government of Cambodia concerning the Prosecution under Cambodian Law of Crimes Committed during the Period of Democratic Kampuchea (adopted 6 June 2003, entered into force 29 April 2005) 2329 UNTS 117. 
countries, especially victims, and benefitted from the expertise and financial resources that the UN is able to marshal in support of them.

In 2010, UN Secretary-General Ban Ki-Moon's Guidance Note on transitional justice shifted the structural and substantive relationship between international law and transitional justice such that international actors, legal obligations and standards (norms and policies) are to drive or determine the content of transitional justice. This is evidenced by his narrowed understanding of transitional justice as compared to Kofi Annan's 2004 definition:

[T]ransitional justice is the full range of processes and mechanisms associated with a society's attempt to come to terms with a legacy of largescale past abuses, in order to ensure accountability, serve justice and achieve reconciliation. ... Transitional justice consists of both judicial and non-judicial processes and mechanisms, including prosecution initiatives, facilitating initiatives in respect of the right to truth, delivering reparations, institutional reform and national consultations. Whatever combination is chosen must be in conformity with international legal standards and obligations. ${ }^{81}$

In this statement, it is possible to discern two critical shifts in the field of transitional justice. First, the UN no longer seeks to constrain its own conduct but projects its authority over the entire field, seeking to constrain the conduct of States. For example, the UN helps to broker peace agreements and influences their content by invoking international legal obligations and standards. In turn, the UN Security Council has sought to consistently enforce intrastate peace agreements. ${ }^{82}$ By removing the reference to optionality in the 2004 understanding of transitional justice, international involvement in designing transitional justice measures seems to be assumed in the 2010 Guidance Note. The second shift is buttressed by the first. States are no longer bound only by international legal obligations but also by international legal 'standards', which is presumably a reference to norms and policies established by the UN in this field through soft law instruments. In fact, a guiding principle in the 2010 Note is for the UN to "[s] upport and actively encourage compliance with international norms and standards when designing and implementing transitional justice processes and mechanisms".83

\footnotetext{
81 Emphasis added: 2010 Guidance Note, supra note 3, p. 2.

82 G.H. Fox, K. Boon and I. Jenkins, 'The United Nations Security Council and Non-International Armed Conflict', 67:3 American University Law Review (2018) pp. 649-731.

83 Emphasis added: 2010 Guidance Note, supra note 3, p. 2.
} 
In other words, whereas transitional justice began as a concept to describe observed practices that were determined by national actors, it has become one that is managed by the UN and its partners, "such as donors, aid agencies, nongovernmental organisations, and private foundations" ${ }^{84}$ Martti Koskenniemi has described managerialism as follows:

'Managerialism' is an ideology under which the strategic leadership of an institution (or regime) is separated from its assumed beneficiaries in the belief that when a specialised elite of managerial experts carries out strategic choices, then the outcomes for the beneficiaries will be optimal. Under this view the regular staff of the institution is responsible only to the managerial leadership and its performance is assessed by criteria set down by it - criteria only looking for the optimal result. ${ }^{85}$

Anne Orford's definition of managerialism similarly emphasises this division between content creation and reception, as well as the focus on ends over means. ${ }^{86}$

The UN's managerial approach to transitional justice presupposes two things. First, it assumes that a rationally optimised result is possible based on best practices and lessons learned, that there are no fundamentally incompatible legal and policy preferences, as may well be the case within a field as contested as transitional justice. ${ }^{87}$ Second, it engages with transitional justice as though it is a largely result-oriented concept, that process is secondary or insignificant. However, the intersubjective nature of justice would suggest that

842010 Guidance Note, supra note 3, p. 7; A. Anghie and B.S. Chimni, 'Third World Approaches to International Law and Individual Responsibility in Internal Conflicts', 2:1 Chinese Journal of International Law (2003) pp. 77-103, p. 97, citing M. Koskenniemi, C. Schmitt and H. Morgenthau; see also A. Anghie, 'Imperialism and International Legal Theory', in A. Orford and F. Hofffmann (eds.) The Oxford Handbook of the Theory of International Law (Oxford University Press, Oxford, 2016) pp. 156-172.

85 M. Koskenniemi, 'Hegemonic Regimes', in M.A. Young (ed.), Regime Interaction in International Law: Facing Fragmentation (Cambridge University Press, Cambridge, 2012) pp. 305-324, p. 305.

86 A. Orford, 'Book Review Article: International Territorial Administration and the Management of Decolonisation', 59:1 International \& Comparative Law Quarterly (2010) pp. 227-249, p. 246.

87 Koskenniemi, supra note 85, p. 308. 
process matters and can even be transformative, that justice is more than a technical output. 88

In support of its managerial authority, the UN asserts the hegemony of international law in the field of transitional justice. It has insisted that, to be effective, transitional justice efforts "must be grounded in international human rights standards":89

'Hegemony' is ... an analytical tool to examine the everyday phenomenon whereby some particular actor ... seeks to make its particular project or interest or pursuit seem the general project or interest. Under this view, 'hegemony' describes what can also be called a universalisation strategy, the effort by some particular to appear as or to represent the universal. ... International actors typically enter the political scene by claiming to represent or to speak in the voice of the universal. ${ }^{90}$

Unlike international regimes that call into question the adequacy of existing international regimes, ${ }^{91}$ the international transitional justice regime seems to challenge the adequacy of national normative orders (e.g. legal and political) to address issues recognised as transitional injustices. This is evident for example in the introductory lines of the UN Secretary-General's 2010 Guidance Note:

Assisting societies devastated by conflict or emerging from repressive rule to re-establish the rule of law and come to terms with large-scale human rights violations, especially within a context marked by broken institutions, exhausted resources, diminished security, and a distressed and divided population, presents a daunting challenge. ${ }^{92}$

Accordingly, the UN commits itself to the "long-term institutional capacity of UN field presences, transitional administrations and civil society to respond to transitional justice demands". ${ }^{93}$

88 R. Forst, Normativity and Power: Analyzing Social Orders of Justification (Oxford University Press, Oxford, 2017) p. 8.

89 онснR, National Consultations, supra note 61, p. 1; UN Human Rights Council, supra note 69; Summary; Resolution 12/11, supra note 70, para. 20.

9o Koskenniemi, supra note 85, p. 311.

91 Ibid., p. 315.

922010 Guidance Note, supra note 3, p. 3.

93 Ibid., p. 7 . 
Portraying international law and UN expertise as (nearly) wholly occupying the field of transitional justice might be understandable in light of a few considerations. First, there is perceived overlap of the UN's peace and security mandate with the goals of transitional justice, namely accountability, justice and reconciliation. ${ }^{94}$ Second, under international law, the UN's mandate is subject to permissive interpretation, meaning its involvement in an activity is deemed permissible if not explicitly prohibited in the UN Charter and considered necessary for fulfilling an express mandate therein. ${ }^{95}$ Third, transitioning societies face a real risk of sliding back into conflict and, or illiberal politics, making UN engagement buttressed by international law appealing and sensible. ${ }^{96}$ Fourth, hegemony is an intuitive construct given that there are at least four international legal regimes that constrain States' transitional justice options - international human rights law, international humanitarian law, international criminal law and international refugee law. ${ }^{97}$ Perhaps for some or all of these reasons, the UN Human Rights Council in 2012 stated that it welcomes "the activities of the United Nations, including through its field presences, in assisting States to design, establish and implement transitional justice mechanisms and promote the rule of law, as well as its conceptual and analytical work on transitional justice". 98

However, such managerialism and hegemony masks the specific normativity of the UN's approach and that of international legal standards more generally. By using the language of international law to advance policy preferences,

94 Article 1(1): "To maintain international peace and security, and to that end: to take effective collective measures for the prevention and removal of threats to the peace, and for the suppression of acts of aggression or other breaches of the peace, and to bring about by peaceful means, and in conformity with the principles of justice and international law, adjustment or settlement of international disputes or situations which might lead to a breach of the peace;" emphasis added: UN Charter, supra note 76; 2004 Report, supra note 39; 2010 Guidance Note, supra note 3. ICJ, Reparations for Injuries Suffered in the Service of the United Nations, Advisory Opinion, ICJ Rep 1949, p. 174, p. 182.

96 In the first five years post-conflict, there is a 44 per cent risk that hard won peace will give way to a resumption of violence, and a 32 per cent risk that this will occur within the next five years: P. Collier et al., , Breaking the Conflict Trap: Civil War and Development Policy (World Bank, Washington, 2003) p. 83; and P. Collier and A. Hoeffler, 'Conflicts', in B. Lomborg (ed.), Global Crises, Global Solutions (Cambridge University Press, Cambridge, 2004) pp. 129-174.

97 The UN Secretary-General has described these bodies of law as the "four pillars" forming part of the normative foundation of the UN's rule of law work: 2004 Report, supra note 39, p. 5; 2010 Guidance Note, supra note 3, p. 3.

98 Resolution $21 / 15$, supra note 70 , paras. 2-3. 
the transitional justice vocabulary that has emerged falsely expresses itself as content-neutral rather than normative, as true rather than a regime..$^{99}$ There is also a lack of consensus that international law can wholly occupy the field of transitional justice. As discussed below, measures not recognised by international law can also contribute to transitional justice. Furthermore, a hegemonic approach to transitional justice is prone to experts assuming that their preferences are the same as others. ${ }^{100}$ For example, many truth commissions have been established with the same (or similar) mandate and design features, which is likely due to the expertise of those involved in their creation. ${ }^{101}$ Consequently, the UN's East Timor Truth and Reconciliation Commission focused on conflict resolution and not on re-establishing a democratic system, which was also important to the local population. ${ }^{102}$ At the same time, UN officials and experts are not accountable to local populations and may even be considered illegitimate by them. ${ }^{103}$

In the previous section, it was demonstrated inter alia that the normative content of transitional justice has come to be strongly associated with international law and the UN's technical or expert standards. The respective implications of these relationships are arguably the exclusion of sub-national legal orders and a denial of the relevance of politics to this field. In this section, the state of the art is critically analysed, namely, UN understandings of transitional justice that emerge from these associations, consequently marginalised understandings, and corrective measures taken by the UN and recommended by scholars. To be clear, the limited aim here is to consider broad trends in the UN's generation of transitional justice content, relying primarily on the OHCHR's website to identify the relevant instruments. Accordingly, a comprehensive substantive review, which could possibly unearth some divergence in transitional justice content across UN organs and experts, is not attempted. As well, only the normative framework developed in official UN documents is examined, not the UN's field practice, which is supposed to be guided by but also inform

\footnotetext{
99 Koskenniemi, supra note 85, p. 313.

$100 \quad$ Ibid., p. 318.

101 C. Stahn, 'Accommodating Individual Criminal Responsibility and National Reconciliation: The UN Truth Commission for East Timor', 95:4 American Journal of International Law (2001) pp. 952-966, pp. 953-955.

102 Ibid., p. 957.

103 McEvoy, supra note 5, p. 424.
} 
the former. Whether there may be some divergence between a transitional justice mandate received from UN headquarters and the work carried out by UN in-country officials goes beyond the scope of the present inquiry.

\subsection{Hierarchy of Interests}

In his 2004 report, the UN Secretary-General understood the ideal of 'justice' to include the "punishment of wrongs". 104 In this report and the 2010 Guidance Note on transitional justice, international criminal tribunals are given pride of place, with 'other' transitional justice mechanisms regarded as complementing this ideal: "other transitional justice mechanisms ... may need to be put in place in order to overcome the inherent limitations of criminal justice processes - to do the things that courts do not do or do not do well". ${ }^{105}$ Additionally, the UN Secretary-General has taken the position that the UN can never endorse a peace agreement that contains amnesties for genocide, other crimes against humanity, war crimes or gross violations of human rights. ${ }^{106}$

Scholars observe that, beginning with the creation of the ad hoc international criminal tribunals for the former Yugoslavia and Rwanda in the early 199os, and continuing with the establishment of the International Criminal Court in 2002, the idea of trying individuals for crimes under international law such as genocide, other crimes against humanity and war crimes - has come to monopolise understandings of transitional justice at the international level. ${ }^{107}$ If there is any doubt about the prioritisation of international criminal trials, the bottom line speaks volumes. In 2004, these two ad hoc tribunals employed more than 2000 individuals and their combined budgets were equivalent to 15 per cent of the UN's total regular budget. ${ }^{108}$ This retributive justice monopoly has given rise to questions about whether it is empirically justified, as well as the legality of 'alternative' understandings of transitional justice. ${ }^{109}$ In fact, when 'traditional' approaches to justice are accepted in principle, they

1042004 Report, supra note 39, para. 7: "For the United Nations, 'justice' is an ideal of accountability and fairness in the protection and vindication of rights and the prevention and punishment of wrongs. Justice implies regard for the rights of the accused, for the interests of victims and for the well-being of society at large".

105 Ibid., para. 47.

106 Resolution $21 / 15$, supra note 70, para. 7.

107 See for example S.M.H. Nouwen and W.G. Werner, 'Monopolizing Global Justice: International Criminal Law as Challenge to Human Diversity', 13:1 Journal of International Criminal Justice (2015) pp. 157-176; R. Nagy, 'Transitional Justice as Global Project: Critical Reflections', 29:2 Third World Quarterly (2008) pp. 275-289.

1082004 Report, supra note 39, para. 42 (exceeding \$250,000,000 USD).

109 Nouwen and Werner, supra note 107; Nagy, supra note 107. 
can be subject to modification to conform better with international legal standards (as opposed to obligations), as well as legal regulation by transitioning States. ${ }^{110}$ This can result in traditional approaches to justice, like the Rwandan gacaca courts for example, replicating core elements of the criminal justice models for which they sought to be an alternative. ${ }^{111}$

As evidenced in a UN Security Council resolution on the protection of civilians in armed conflict, the focus on retributive justice results in transitional justice being associated with physical violations of civil and political rights for which there are identifiable individual victims and direct perpetrators:

10. [The Council] Affirms its strong opposition to impunity for serious violations of international humanitarian law and human rights law and emphasises in this context the responsibility of States to comply with their relevant obligations to end impunity and to thoroughly investigate and prosecute persons responsible for war crimes, genocide, crimes against humanity or other serious violations of international humanitarian law in order to prevent violations, avoid their recurrence and seek sustainable peace, justice, truth and reconciliation;

11. Recalls that accountability for such serious crimes must be ensured by taking measures at the national level, and by enhancing international cooperation in support of national mechanisms, draws attention to the full range of justice and reconciliation mechanisms to be considered, including national, international and "mixed" criminal courts and tribunals, and truth and reconciliation commissions, as well as national reparation programs for victims and institutional reforms; and underlines the Security Council's role in ending impunity; ${ }^{12}$

The strong association between transitional justice and retributive justice also surfaces in the right to the truth. In a UN General Assembly resolution adopted on this right in 2014, the Assembly is:

Convinced that States should preserve archives and other evidence concerning gross violations of human rights and serious violations of international humanitarian law to facilitate knowledge of such violations, the

110 R. Nagy, 'Centralizing Legal Pluralism? Transitional Justice in Transitional Contexts', in C.L. Sriram et al. (eds.), Transitional Justice and Peacebuilding on the Ground: Victims and Ex-Combatants (Routledge, London, 2013) pp. 81-100.

111 Ibid.

112 UN Security Council, Resolution 1894 (2009) (UN Doc. S /RES/1894 (2009)), paras. 10-11. 
investigation of allegations and the provision for victims of access to an effective remedy in accordance with international law. ${ }^{113}$

However, national transitional justice experiences demonstrate that a right to truth may also be relevant to the authority of transitional leaders to determine the content of transitional justice measures - whether their undisclosed personal financial or other interests conflict with their holding public office. Just consider the example of Lech Walęsa, iconic dissident and the first elected post-communist leader of Poland. It was recently learned that he collaborated for years with the communist secret police before leading Solidarity. ${ }^{114}$ As President of Poland, he actively worked to suppress access to secret police archives when citizens lobbied for them to be opened. ${ }^{115}$ In this context, a right to truth could serve to promote the full disclosure by candidates running for office of their involvement in the previous regime.

In addition to favouring retributive justice for crimes under international law as ideal transitional justice, the UN has attempted to significantly narrow this field by determining what a transitional justice mechanism or response is. In 2004 and 2010, the UN Secretary-General referred to transitional justice as constituting a "full range of processes and mechanisms associated with a society's attempts to come to terms with a legacy of large-scale past abuses ... [and comprising] both judicial and non-judicial mechanisms...".116 The breadth of this statement encompasses all manner of transitional justice responses - legal and political, international and local, exceptional and ordinary, immediate and longterm. However, in the 2010 Guidance Note, UN Secretary-General Ban Ki-moon goes on to state that transitional justice is "by definition exceptional and of limited duration".117 Rather than favouring one type of transitional justice and rendering other forms 'alternatives' to it, this statement drastically circumscribes what can ever be recognised and supported as a transitional justice measure.

If transitional justice responses are 'by definition' exceptional and of limited duration, then this descriptive requirement supplants any purposive or functional approach that might be taken to designing and discerning transitional justice measures that expressly aim to or in fact respond to large-scale past

113 Emphasis added. UN General Assembly, Resolution 68/165 (UN Doc. A/REs/68/165 (2014)), p. 2 (preamble).

114 M. Nalepa, Skeletons in the Closet: Transitional Justice in Post-Communist Europe (Cambridge University Press, Cambridge, 2010), Epilogue.

115 Ibid.

1162004 Report, supra note 39, para. 8; 2010 Guidance Note, supra note 3.

1172010 Guidance Note, ibid., p. 6. 
abuses. Instead, the UN's understanding of transitional justice becomes frozen, reflecting the earliest observed transitional justice practices - truth commissions, trials for crimes under international law, vetting procedures, reparations programmes and so on. But why should citizens in countries emerging from conflict or repressive rule today be bound by these nationally and historically contingent understandings of transitional justice? Surely justice is an intersubjective concept whose meaning varies greatly amongst individuals. The UN's narrow understanding of transitional justice can also undermine international law's universality, the conditions it establishes for multiple actors to pursue multiple purposes without requiring their endorsement of any of them. ${ }^{118}$

\section{2 $\quad$ Marginalized Injustices}

A hierarchy of interests in the field of transitional justice has emerged, which evidences regime formation. ${ }^{119}$ This regime prioritises gross violations of international civil and political rights and retributive justice responses to them. It also defines transitional justice as exceptional and of limited duration. So what injustices does this regime risk marginalising?

Scholars have identified four overlapping categories of injustices amounting to large-scale past abuses that confront transitioning societies and have been marginalised over the years: (1) systemic or structural injustices, and their legacies, for which there is no direct perpetrator; (2) distributive (socio-economic) injustices (e.g. lack of access to land) that cannot be fully addressed by exceptional short-term initiatives (e.g. truth commissions); (3) 'ordinary' criminal injustices (e.g. corruption and other economic crimes), including some that spike in the early phases of a transition (e.g. homicides and domestic violence); and (4) transitional injustices that are addressed through 'ordinary' laws or politics (e.g. education and media laws). ${ }^{120}$ These marginalised categories of injustices powerfully illuminate the non-neutrality of the UN's transitional justice regime. Its hierarchy of strategic interests leads to prioritising individual culpability over systemic discrimination, civil and political rights over economic and social rights, crimes under international law over ordinary crimes, law over politics and exceptional short-term justice over ordinary longterm justice to address large-scale past abuses.

118 M. Koskenniemi, 'International Law: Constitutionalism, Managerialism and the Ethos of Legal Education', 1 European Journal of Legal Studies (2007) pp. 1-18, p. 2

119 Koskenniemi, supra note 85, p. 320.

120 R. Mani, 'Dilemmas of Expanding Transitional Justice, or Forging the Nexus between Transitional Justice and Development', 2 Journal of International Transitional Justice (2008) pp. 253-265; McEvoy, supra note 5. 
The first category covers discrimination against particular groups or communities, resulting in social injustices and patterns of structural violence. ${ }^{121}$ For example, Rama Mani recalls efforts to culturally destroy various First Nations groups and Indigenous peoples, the totality of Apartheid's humiliations for black South Africans, policies that contributed to the genocides in Rwanda and Burundi, and Hindu upper caste domination in Nepal to the detriment of lower castes and Buddhists. ${ }^{122}$ Insufficient attention has been paid to structural violence in the field of transitional justice. ${ }^{123}$ And even on the rare occasion that attention is paid, redress remains a huge challenge. For example, the South African Truth and Reconciliation Commission recommended a 'white tax' to acknowledge the racial structure of Apartheid that financially privileged white South Africans for hundreds of years. ${ }^{124}$ Although affirmative action programmes are in place, this recommendation was not implemented.

The second category concerns distributive injustices that pre-date authoritarian rule or conflict, are perpetuated by them, and are often prioritised by victims post-transition over international conceptions of transitional justice. For example, empirical research carried out in Nepal, Kenya, Uganda, and the Democratic Republic of the Congo illustrates the prioritisation of distributive justice, basic survival and security over retributive justice. ${ }^{125}$ However, as with the first category of injustices, transitional justice mechanisms such as truth commissions often lack the mandate, funding, time and expertise to design wide-reaching policies of social and economic reform. ${ }^{126}$ As for reparations,

121 J. Galtung, 'Violence, Peace and Peace Research', 6:3 Journal of Peace Research (1969) pp. 167-191.

122 Mani, supra note 120, pp. 254-255; P. Uvin, Aiding Violence: The Development Enterprise in Rwanda (Kumarian Press, Inc., West Hartford, CT, 1998).

123 J. Nevins, 'Restitution over Coffee: Truth, Reconciliation, and Environmental Violence in East Timor', 22:6 Political Geography (2003) pp. 677-701.

124 V. Nesiah, 'Theories of Transitional Justice: Cashing in the Blue Chips', in Orford and Hofffmann (eds.), supra note 84, pp. 779-796, p. 794.

125 For a short summary of the empirical research, see L. Waldorf, 'Anticipating the Past: Transitional Justice and Socio-Economic Wrongs', 21:2 Social \& Legal Studies (2012) pp. 171-186, p. 175 (including cited materials).

126 J.L. Cavallaro and S. Albuja, 'The Lost Agenda: Economic Crimes and Truth Commissions in Latin America and Beyond', in K. McEvoy and L. McGregor (eds.) Transitional Justice from Below: Grassroots Activism and the Struggle for Change (Hart Publishing, Oxford, 2008) pp. 121-141. The authors are receptive to truth commissions addressing economic crimes and corruption. 
of the 84 transitions that have occurred between 1970 and 2004, only 14 implemented such programmes. ${ }^{127}$

The third category includes, but is not limited to, war economies of corruption and exploitation. These practices rob transitioning societies of natural, mineral and financial resources that are essential to their post-conflict development. And individuals implicated in these practices may become posttransition leaders with conflicts of interest that compromise their ability to negotiate and lead a transition. Although Sierra Leone decided that blood diamond profits should be used to pay reparations to victims of the conflict, and Liberia's Truth and Reconciliation Commission was mandated to investigate economic crimes, these examples are the exception rather than the rule. Moreover, these general measures are not a substitute for addressing the most basic security concerns of people in transitioning societies.

The fourth category points to the underexamined role inter alia of constitutional law, legislation and politics in contributing to transitional justice. For example, victims of Apartheid attempted to challenge the amnesty provision in South Africa's interim (temporary) Constitution. ${ }^{128}$ In upholding the provision, the Constitutional Court of South Africa weighed the victims' claims for justice against the Constitution's role as a 'bridge' to peace and reconciliation. Indeed, transitional justice has been theorised as a social contract, an idea that also underpins modern constitutionalism. ${ }^{129}$ As for ordinary legislation, it is necessary for regulating key public sector goods that may need to be de-weaponised, such as education, media, elections and security.

In terms of politics, it is helpful to consider just one example of how even a small political transitional justice measure can be transformative for its participants. In the summer of 2016, the Colombian government announced that a settlement of demobilised FARC rebels would be established in La Paz, a town that had been terrorised by FARC fighters during the civil war and whose

127 Ibid., p. 177.

128 Constitutional Court of South Africa, People's Organization (AZAPO) v. The President of the Republic of South Africa, 1996(4) SALR 671, paras. 4, 19 and 22. See also European Court of Human Rights, Case of Sejdic and Finci v. Bosnia and Herzegovina, Judgment, Application Nos. 27996/o6 and 34836/06, 22 December 2009. The Court held that the prohibition against discrimination is violated by the ethnically based representation provisions in the Constitution for Bosnia and Herzegovina, which was drafted as part of the Dayton Accords. However, it refrained from deciding whether preserving peace is a reasonable justification for retaining some form of this arrangement.

129 P. de Greiff, 'A Normative Conception of Transitional Justice', 50 Politorbis (2010) pp. 17-29, p. 18. It is concerned with realising "two mediate goals, namely recognition and civic trust, and two final goals, reconciliation and democracy". 
mayor was gunned down in 1997. In October 2016, following a national referendum on the peace agreement with FARC, in which the 'no' vote won by a narrow margin, a public meeting was convened in La Paz to air grievances.

$[\mathrm{H}]$ undreds gathered in a municipal park, as church leaders, politicians and rebel leaders discussed the [peace] deal. Victims took the microphone and told of their loved ones who were killed during the war. Mr. Altamiranda [the FARC commander in La Paz] gave a public apology for the rebels' crimes. The events managed to move leaders like Sol Marina Torres, 39, a member of the Democratic Center, the right-wing party that led the campaign against the [peace] deal and is continuing efforts to scuttle it. Ms. Torres decided to side against her party's leaders and support the guerrilla presence in her town, saying there was no choice but to make peace. ${ }^{130}$

This example suggests that an international transitional justice regime may not only diminish the political dimension of the field, but may also assume that transitional justice measures, being exceptional, must therefore be large-scale. ${ }^{31}$

\subsection{Correctives}

\subsubsection{United Nations}

UN experts seem cognisant that their transitional justice regime has at times contributed to the marginalisation of categories of injustices. Their response has been to expand the scope of their work in transitioning societies in terms of jurisdiction, subject-matter and constituencies served. This expansion has occurred mainly under the following three rubrics that the UN closely associates with transitional justice: the rule of law; the goal of non-recurrence; and the root causes of conflict. Additionally, the UN's understanding of transitional justice has expanded slightly through inter alia its focus on protecting women and children, as well as the international human right of citizens to participate in the conduct of public affairs, which is protected under Article 25(1) of the International Covenant on Civil and Political Rights (1966).132

In his 2004 report titled The Rule of Law and Transitional Justice in Conflict and Post-Conflict Societies, the UN Secretary-General decisively linked transitional

130 N. Casey, 'Unease in Colombia, as Old Enemies Become New Neighbors', The New York Times, 4 February 2017.

131 Koskenniemi, supra note 85, p. 316.

132 Supra note $5^{2}$. 
justice to the rule of law. ${ }^{133}$ This report can be traced to a UN Security Council meeting at the ministerial level at which the role of the UN in "establishing justice and the rule of law in post-conflict societies" was discussed. ${ }^{134}$ Kofi Annan's report followed and offers the following examples of the UN's rule of law work in transitioning societies:

strengthen domestic law enforcement and justice institutions, facilitate national consultations on justice reform, coordinate international rule of law assistance, monitor and report on court proceedings, train national justice sector officials, support local judicial reform bodies and advise host country rule of law institutions. Our operations have helped national actors vet and select national police, judges and prosecutors, draft new constitutions, revise legislation, inform and educate the public, develop ombudsman institutions and human rights commissions, strengthen associations of criminal defence lawyers, establish legal aid, set up legaltraining institutes and build the capacity of civil society to monitor the justice sector. ${ }^{135}$

Annan goes on to add that, in terms of transitional justice measures, "[p]eace missions have also helped host countries to address past human rights abuses by establishing tribunals, truth and reconciliation mechanisms and victim reparation programmes". ${ }^{136}$ What is striking when one juxtaposes the UN's rule of law work and its transitional justice work is that the former is overtly ordinary, long-term and forward-looking, whereas the latter is exceptional, timelimited and backward-looking. However, it is not at all clear why transitional justice, addressing past large-scale abuses, cannot also be pursued through ordinary, long-term and forward-looking measures. Nevertheless, the distinction between these two concepts has for the most part remained (even if rhetorically

1332004 Report, supra note 39, para. 6: "The "rule of law" is a concept at the very heart of the Organization's mission. It refers to a principle of governance in which all persons, institutions and entities, public and private, including the State itself, are accountable to laws that are publicly promulgated, equally enforced and independently adjudicated, and which are consistent with international human rights norms and standards. It requires, as well, measures to ensure adherence to the principles of supremacy of law, equality before the law, accountability to the law, fairness in the application of the law, separation of powers, participation in decision-making, legal certainty, avoidance of arbitrariness and procedural and legal transparency".

134 Ibid., para. 1.

135 Ibid., para. 12.

136 Ibid. 
blurred on occasion), while continuing to be closely linked to one another in soft law instruments. Accordingly, the UN Security Council has referred to the rule of law and transitional justice in more than 160 resolutions since 2004. ${ }^{137}$ By invoking the two concepts simultaneously, the UN's work in a conflict or post-conflict country expands considerably, thereby partially responding to critiques of marginalisation, all while maintaining a narrow understanding of transitional justice.

The goal of non-recurrence has also served as a useful concept for expanding the UN's work in transitioning societies while maintaining its narrow understanding of transitional justice. Non-recurrence is a goal of transitional justice that first appears in Joinet's 1997 principles to combat impunity for gross human rights violations and is described as follows:

The State shall take appropriate measures to ensure that the victims do not again have to endure violations which harm their dignity. Priority consideration shall be given to:

a. Measures to disband parastatal armed groups;

b. Measures repealing emergency provisions, legislative or otherwise, which are conducive to violations;

c. Administrative or other measures against State officials implicated in gross human rights violations. ${ }^{138}$

Initially then, the goal of non-recurrence obliged transitioning States to consider disbanding non-State armed forces, repealing offending legislation, abolishing emergency courts and removing offenders from official posts. ${ }^{139}$ Over time, however, the goal of non-recurrence has expanded to require State action and more of it. Today, the goal of non-recurrence imposes duties on transitioning States to reform national laws and institutions: "Legislative measures necessary to ensure protection of human rights and to safeguard democratic institutions and processes must be enacted."140 Monitoring this work is inter alia

137 UN Security Council, The Rule of Law and Transitional Justice in Conflict and Post-Conflict Societies: Report of the Secretary-General (UN Doc. S/2011/634), para. 10 (2011 Report).

138 Joinet Principles, supra note 19, Principle 37.

139 Ibid., Principles 37-41.

140 Emphasis added.Joinet/Orentlicher Principles, supra note 28, Principle 38. The UN Secretary-General echoes this positive legal duty, 2004 Report, supra note 39, p. 2, as does the Council of the European Union, supra note 49, p. 2o. See also C. Hesse and R. Post, Human Rights in Political Transitions: Gettysburg to Bosnia (MIT Press, Cambridge, 1999). 
the Special Rapporteur on the Promotion of Truth, Justice, Reparation and Guarantees of Non-Recurrence. ${ }^{141}$

Like the concept of the rule of law, the goal of non-recurrence has normatively supported the UN's long-term, national and forward-looking institutional reform work in transitioning societies while allowing the narrow concept of transitional justice to remain largely intact. ${ }^{142}$ In 2014, the ОНCHR succinctly described the relationship between transitional justice and the goal of nonrecurrence as follows:

Guarantees of non-repetition are essential to combat impunity for violations of human rights and humanitarian law and to effectively tackle the root causes of conflict and repression. While they are a form of reparation, they fulfil other aims such as preventing such violations from happening again. They are also forward-looking as they benefit society as a whole, and not only victims. In the context of transitional justice, institutional reform refers to guarantees of non-repetition aimed at reforming State structures and institutions that facilitated or promoted such violations. $^{143}$

This passage sheds more light on the UN's understanding of transitional justice. To the extent that a measure benefits more than victims of large-scale past abuses, it is not regarded as falling within the core meaning of transitional justice. This approach therefore excludes laws of general application even if the impetus for their enactment was large-scale past abuses. Such legislation, however - consider for example the landmark American Civil Rights Act of 1964 - can be an important response to structural injustices and should arguably be regarded as constituting a transitional justice response.

The goal of non-recurrence is also linked to addressing the 'root causes' of past abuses, a third concept invoked by the UN to expand its work in transitioning societies. In his 2010 Guidance Note, the UN Secretary-General strongly advocated that transitional justice "processes and mechanisms take account of the root causes of conflict and repressive rule, and address violations

141 UN Human Rights Council, Resolution 18/7: Special Rapporteur on the Promotion of Truth, Justice, Reparation and Guarantees of Non-Recurrence (UN. Doc. A/HRC/REs/18/7 (2009)). The first Special Rapporteur was Pablo de Greiff, Director of Research at the ICTJ.

142 OHCHR Report, supra note 68.

143 онснв, Transitional Justice and Economic, Social and Cultural Rights (UN Doc. $\mathrm{HR} / \mathrm{PUB} / 13 / 5)(2014)$, p. 44. 
of all rights, including economic, social and cultural rights".144 Prior to this, the 2005 Pinheiro Principles on Housing Property Restitution for Refugees and Displaced Persons were perhaps the most significant transitional justice instrument addressing violations of these rights. ${ }^{145}$ Endorsed by the UN SubCommission on the Promotion and Protection of Human Rights, they were the product of seven years of consultations with experts and stakeholders, as well as a comparative study of national restitution policies and practices. The Principles contain best practices and carefully distinguish between mandatory international legal obligations on the one hand, and recommended policies or best practices on the other. ${ }^{146}$

The Guidance Note contains several recommendations for addressing economic, social and cultural violations, including inter alia through national criminal laws, national policies and protective national rights legislation. ${ }^{147}$ In this way, the Note implicitly acknowledges that ordinary national crimes, policies and laws can and do fall within the purview of transitional justice. The Note may also implicitly acknowledge the political and long-term dimensions of transitional justice, which were expressly acknowledged in the UN SecretaryGeneral's 2004 report on transitional justice.

In 2014, however, the OHCHR changed course in its report on transitional justice and its relationship to economic, social and cultural rights. ${ }^{148}$ It considered the potential of exceptional and time-limited transitional justice mechanisms to address violations of these rights (e.g. truth commissions, judicial and quasi-judicial proceedings, reparations), obstacles to these, and how to determine which rights violations fall within the scope of transitional justice. ${ }^{149}$ In the report, consideration is not given to how ordinary, long-term and forwardlooking national laws and policies can address such violations. In fact, the report considers how institutional reform can address the root causes of conflict but makes clear that this inquiry falls under the goal of non-recurrence rather than transitional justice proper. ${ }^{150}$

1442010 Guidance Note, supra note 3, pp. 7 and 10.

145 UN Commission on Human Rights, Final Report of the Special Rapporteur, Paulo Sérgio Pinheiro: Principles on Housing and Property Restitution for Refugees and Displaced Persons (UN Doc. E/CN.4/Sub.2/2005/17).

146 Ibid.

1472010 Guidance Note, supra note 3, p. 10.

148 OHCHR, supra note 143.

149 Ibid.

150 Ibid., p. 44. 
As the UN expands its work in transitioning societies while attempting to conceptually distinguish transitional justice from national legal and political reforms, it becomes increasingly difficult to justify the UN's authority to expertly manage this field and assert international law's hegemony within it. How can one so neatly compartmentalise the latter reforms as relevant to the rule of law, the goal of non-recurrence and the root causes of conflict, but not to transitional justice proper? Who can legitimately determine what a transitional justice response is, what falls within and outside of these boundaries? By drawing these distinctions, the UN is also able to advance a concept of transitional justice that is less rife with normative contestation. If national institutional, legislative and policy reforms were brought into the conceptual fold, it would be much harder to maintain the hierarchy of interests forming the core of transitional justice.

In addition to these conceptual developments, the UN has expanded the contexts in which its transitional justice work is done. In the Secretary-General's 2010 Guidance Note, it is recommended that the UN's transitional justice activities should extend to peace processes, during which international human rights and transitional justice should be taken into account. ${ }^{151}$ Additionally, transitional justice should be coordinated with disarmament, demobilisation and reintegration efforts. ${ }^{152}$

The Note also strongly recommends that transitional justice initiatives better protect particular constituencies, namely women and children. ${ }^{153}$ The result of these recommendations is soft law instruments that focus on women and children in the context of transitional justice. ${ }^{154}$ The UN has therefore acknowledged the importance, for example, of legislation enacted in Sierra Leone, Colombia, Nepal, Rwanda and Uganda to address women's security with respect to violence, as well as issues concerning their families, property and land tenure. ${ }^{155}$ This includes judicial, security sector and institutional reform, as well as the enactment of legislation that better protects women and children from conflict-related violence and human rights violations. ${ }^{156}$ As well, UNICEF has studied the experiences of children in transitional justice processes and

\footnotetext{
1512010 Guidance Note, supra note 3.

152 Ibid.

153 Ibid., pp. 4-5.

154 The OHCHR's website provides access to transitional justice instruments related to gender and children: <www.ohchr.org/EN/Issues/TruthJusticeReparation/Pages/InternationalInstruments.aspx $>$, visited on 16 January 2019 .

1552011 Report, supra note 137, para. 43

1562010 Guidance Note, supra note 3, para. 2.
} 
started to articulate principles that could guide child-sensitive approaches to transitional justice in the future. ${ }^{157}$ In its normative work to protect particularly vulnerable segments of society, therefore, the UN has on occasion implicitly admitted the relevance of ordinary national laws and policies to the field of transitional justice. This work seems to also implicitly acknowledge that a State-centred approach to transitional justice may be inadequate to address a structural injustice or what Rainer Forst has termed a "situation of multiple domination" within society. ${ }^{158}$

Finally, the UN's understanding of transitional justice encourages national consultations. In 2004, the UN Secretary-General seemed to imply that the authority to determine the content of transitional justice might rest with transitioning societies themselves and that the UN should facilitate the exercise of that authority:

The role of the United Nations and the international community should be solidarity, not substitution. ... The most important role we can play is to facilitate the processes through which various stakeholders debate and outline the elements of their country's plan to address the injustices of the past and to secure sustainable justice for the future, in accordance with international standards, domestic legal traditions and national aspirations. In doing so, we must learn better how to respect and support local ownership, local leadership and a local constituency for reform, while at the same time remaining faithful to United Nations norms and standards. 159

Since then, however, the UN has repeatedly offered instrumental justifications for national consultations, emphasising that they are desirable because they lead to more meaningful and effective transitional justice outcomes. ${ }^{160}$ Indeed, the success of transitional justice measures depends largely on their perceived legitimacy amongst affected populations. ${ }^{161}$ The UN's support for

157 M.J. Roseman, S. Parmar, T. Sowa and S. Siegrist (eds.), Children and Transitional Justice: Truth-Telling, Accountability and Reconciliation (Human Rights Program, Harvard Law School, Cambridge, 2010).

${ }_{15} 8$ Rainer Forst, The Right to Justification: Elements of a Constructivist Theory of Justice (Colombia University Press, New York, 2012) p. 257.

1592004 Report, supra note 39, para. 17.

16o Ibid.; 2010 Guidance Note, supra note 3, p. 9; онснR, National Consultations, supra note 61 .

1612004 Report, supra note 39; 2010 Guidance Note, supra note 3; Council of the European Union, supra note 49, p. 2; J. Ramji-Nogales, 'Designing Bespoke Transitional Justice: 
national consultations is consistent with an explosion of transitional justice policy frameworks produced by international actors (experts) that urge or require consultation with local actors in the design of mechanisms to ensure their 'local ownership' and effectiveness. ${ }^{162}$ However, justifying national consultations as a means to optimise results belongs to expert managerialism, authority that distinguishes between the ultimate creators of transitional justice content and the recipients of it, between authors and addressees. ${ }^{163}$

In 2009, the OHCHR expressly linked national consultations for transitional justice to Article 25(1) of the ICCPR which states:

Every citizen shall have the right and the opportunity, without any of the distinctions mentioned in article 2 and without unreasonable restrictions: (a) To take part in the conduct of public affairs, directly or through freely chosen representatives; $; 64$

The онсHR clarified, however, that Article 25 is not a right to legally bind officials:

views should be taken into account in a conscientious and respectful manner but [Article 25] does not carry with it the expectation that those views will be acted on. This is the only possible approach in a democratic society where the authorities must balance the demands of the various elements of the society in the context of a limited range of options and of finite resources. It may also guard against majoritarian tendencies, whereby the demands of the many would overwhelm the rights and entitlements of minority groups. ${ }^{165}$

While this statement correctly describes the relationship between citizens and their freely and fairly elected representatives, it does not address how, if at all, the UN respects this right when it assumes the authority to define the content of transitional justice. Stated differently, Article 25 makes clear that the right to

A Pluralist Process Approach', 32 Michigan Journal of International Law (2010) pp. 1-72; P. Lundy and M. McGovern, 'Whose Justice? Rethinking Transitional Justice from the Bottom Up', 55:2 Journal of Law and Society (2008) pp. 265-292.

162 See for example Council of the European Union, supra note 49, p. 8; ICTJ <www.ictj.org/ gallery-items/participation>, visited on 18 January 2019.

163 Orford, supra note 86, pp. 237-239.

164 OHCHR, National Consultations, supra note 61.

165 Ibid., p. 27. 
take part in the conduct of public affairs cannot be 'unreasonably restricted'. It may therefore be asked whether the UN's transitional justice policies or 'standards' unreasonably restrict this right, whether a state of emergency or necessity exists in these countries, and if so, what normative significance that might have. For example, is this right reasonably restricted when the UN Security Council enforces an intrastate peace agreement signed by unelected parties to a conflict and that agreement contains UN-negotiated transitional justice measures? More fundamentally, do international understandings of transitional justice and victimhood reasonably restrict the scope of national consultations? A consultation on the design of a truth and reconciliation commission for defined victims is much more limiting than a consultation to discuss what constitutes a transitional injustice and how to respond to these abuses. Does the UN's assumed involvement in transitional justice efforts reasonably restrict the ability of citizens to determine whether they want this involvement?

Indeed, the answers to these questions will likely vary depending on the context. In Guatemala, for example, rather than assuming involvement, the $\mathrm{UN}$ responded to a request from the government to assist it with establishing the International Commission Against Impunity in Guatemala. ${ }^{166}$ Although not a traditional transitional justice mechanism, insofar as it focuses on actual crime rather than past corruption, it does conform to the UN's understanding of transitional justice in several ways. The mechanism is exceptional and timelimited, and it focuses on criminal justice. However, it remains to be seen if and how this model will inform the UN's understanding of transitional justice, whether it will enrich it or be filed as a 'rule of law' effort that is distinct from transitional justice 'properly understood.' 167

On balance, the UN's work in transitioning societies has expanded while, with some exceptions, retaining a narrow and contingent understanding of transitional justice. Most importantly, the UN has maintained its expert authority in this field and the hegemony of international law buttressing this authority. This international legal and technical approach to transitional justice is not as neutral as it first appears, as it continues to largely deny the transformative role that national laws and politics can play in this field. ${ }^{168}$ At

166 Agreement between the United Nations and the State of Guatemala on the Establishment of an International Commission against Impunity in Guatemala, 12 December 2006, UN Juridical Yearbook (2006) pp. 55-61, preamble.

167 T. Nyberg, 'International Commission Against Impunity in Guatemala: A Non-Traditional Transitional Justice Effort', 28:1 Revue québécoise de droit international (2015) pp. 157-184.

168 Koskenniemi, supra note 85, p. 313: "the brilliance of a hegemonic regime based on 'true' technical language is that it does not present itself as a regime at all". 
bottom, the UN's responses to marginalised injustices rest on its own authority - its experts and good offices - as well as what can be expressed in the language of international law, which are key normative constraints.

\subsubsection{Scholars}

In transitional justice scholarship, it is possible to identify five types of correctives for bringing marginalised transitional injustices into the conceptual fold. First, some have tried to develop a sufficiently strong nexus between the currently narrow concept of transitional justice and grave injustices that fall outside of it (nexus approach). ${ }^{169}$ Second, arguments have been made to expand the concept of transitional justice (conceptual expansion). ${ }^{170}$ Third, some have advocated for the design of international transitional justice mechanisms in greater consultation with the local communities they intend to serve (greater consultation). ${ }^{171}$ Fourth, it has been argued that international criminal justice should make room for other forms of justice (conceptual retreat). ${ }^{172}$ And a fifth approach is to attempt to recast neglected abuses, such as corruption, as constituting a crime under international law (conceptual absorption). ${ }^{173}$

Despite their merits, these approaches raise some concerns. To varying degrees, the first four types of arguments appear to be instrumental - the approach favoured is defended on the basis that it will better meet the needs of victims, improve the legitimacy of transitional justice mechanisms, or because the desired result is more just. Further, they point to no law or legal practice that requires relevant international actors to acknowledge the conceptual reforms sought. Because these arguments are external to the international legal framework that they seek to pierce, they are also vulnerable to being defeated on the basis of seeking to 'colonize' the 'proper legal domain' of transitional justice. ${ }^{174}$ The fifth type of argument is internal to the international legal framework. However, this approach is also somewhat discomfiting. Underlying

169 Mani, supra note 120.

170 Ibid.; P. Arthur (ed.), Identities in Transition: Challenges for Transitional Justice in Divided Societies (Cambridge University Press, Cambridge, 2014); L. Arbour, 'Economic and Social Justice for Societies in Transition', 40:1 NYU Journal of International Law and Politics (2007) pp. 1-27; R. Mani, Beyond Retribution: Seeking Justice in the Shadows of War (Blackwell Publishers, Oxford, 2002).

171 Ramji-Nogales, supra note 161.

172 See for example Nouwen and Werner, supra note 107.

173 I. Bantekas, 'Corruption as an International Crime and Crime against Humanity: An Outline of Supplementary Criminal Justice Policies', 4:3 Journal of International Criminal Justice (2006) pp. 466-484.

174 Bell, supra note 1. 
it is the possible instrumental co-option of a body of law with the result that the legal force of the latter may be diluted - this argument is already being made about international human rights law. ${ }^{175}$

Fundamentally, however, none of the arguments challenge the UN's assumed expert authority in this field or its assertion of international law's hegemony. They do not challenge the existence of an international transitional justice regime with strategic hierarchies or the fact that there is no universally recognised common good underpinning this regime. The purported universality of international human rights, a body of international laws, cannot stand in for a universal understanding of transitional justice, which is a normatively contested and intersubjective concept, or universal understandings of the field's goals: accountability, justice and reconciliation. As Koskenniemi rightly observes:

Instead of through formal dispute settlement or legislation ... regimes develop through the informal expansion of their vocabularies in academia and in bureaucracies and by occupying the position of dominant frameworks of thought and action, matrices for the identification of problems and thumb-rules for their resolution. They operate less as systems of formal commands than as broad cultural or professional orientations that do not respond to problems but act as mechanisms that make it possible to identify an aspect in the world as a 'problem' in the first place. As frameworks of thinking and 'regimes of truth' they operate beyond the consciousness of single individuals or collectives (such as professional groups). ${ }^{176}$

In sum, even if all of the recommendations of scholars were implemented, the normative expansion of transitional justice - what constitutes a large-scale past abuse and what counts as a transitional justice response - would remain normatively constrained by the UN's authority and international law's hegemony within this field.

\section{4 \\ Conclusion}

At the 1988 meeting on transitional justice, Louis Henkin and Theodor Meron were at a loss as to the relevance of international law to the concept of

\footnotetext{
175 George Letsas, for example, argues that not all international human rights are binding legal rights: Presentation, European Society of International Law, University of Zurich, 2-day Symposium on the $50^{\text {th }}$ Anniversary of the Adoption of the ICCPR and the ICESCR, 14-15 April 2016.

176 Koskenniemi, supra note 85, p. 317 .
} 
transitional justice, rubbing sticks of wood together in vain. Today, it is difficult to conceive of transitional justice without reference to the thick normative framework established by the UN and embedded in international law. To be sure, this regime has made many positive contributions to transitioning societies, supporting justice initiatives that would perhaps not be possible otherwise owing inter alia to legal barriers, limited resources or a lack of political will. However, this regime contains a hierarchy of interests and does not overtly admit normative contestation. As a result, citizens are constrained in selecting transitional justice responses or else select responses that fall outside of this regime and are therefore not captured by it. This regime also reflects a particular understanding of transitional justice that diminishes the role of national legal and political orders, and assumes the need for international involvement in a normative sense, implicitly regarding transitioning societies and its members as unable or unwilling to conceive of transitional justice themselves. ${ }^{177}$ Normative expansion, when it occurs, is regime-specific and depends on experts within it to do this work. But where does the greatest normative expansion originate from if not the needs and imaginations of individuals in transitioning societies? If this is the case, is the answer to strengthen this international regime and give it the tools to catch up with developments on the ground in a conceptually authentic manner? Or is there another way forward? 178

\footnotetext{
1772010 Guidance Note, supra note 3. Normative support is used here to distinguish from UN support in the form of human, financial and material resources.

${ }_{178}$ I am enormously grateful to Kristen Bartenstein, Claus Kreß, Larissa van den Herik and the anonymous reviewers for commenting on various drafts of this article, as well as Christian Marxsen and Sarah Nouwen for commenting on a condensed version of the arguments presented here. I also sincerely thank Anne Peters and Christian Walter for supporting this research project, as well as former Editor-in-Chief Ulf Linderfalk for kindly inviting me to address this Journal's Board of Editors at their annual meeting in January 2018. My presentation was based on a draft of this paper, and the feedback I received from Board members and Lund University students on that occasion advanced my thinking about this topic in important ways.
} 